\title{
Ways of commercialization of agricultural land
}

\author{
Yanina Zaitseva ${ }^{1, *}$ \\ ${ }^{1}$ Kuban State Agrarian University named after I.T.Trubilin, Krasnodar, Russia
}

\begin{abstract}
The paper analyzes the ways of commercialization of agricultural land in the Krasnodar Krai. The same mechanism of supply and demand operates in the land market as in all other markets. The main factors of stabilization and growth of demand are considered. The dynamics of changes in the average indicators of agricultural land lease is presented. Proposals have been made for the enforcement of the rights of municipalities to register huge areas of ownerless, uncultivated agricultural land in shared ownership under municipal ownership in order to involve them in civil commerce, to increase local budget revenues from the use of these lands.
\end{abstract}

\section{Introduction}

In the context of the global financial crisis, the agricultural industry is one of the most attractive areas for long-term investments, which is associated with a constant and stable demand for agricultural products both on the domestic and world markets. In the long term, a strategic approach to investing in agricultural production will bring a stable income that does not depend on fluctuations in foreign exchange and stock markets for investors of any industry [1].

In recent years, the agricultural sector of the Krasnodar Krai has shown positive dynamics, which has a positive effect on its attractiveness for investors, including foreign ones. Foreign investors are actively investing in agricultural enterprises and industrial complexes for processing agricultural products.

\section{Materials and methods}

Due to climatic conditions and the pace of development of the agricultural sector, Krasnodar Krai remains one of the leading food production regions of the Russian Federation. Nowadays, a highly developed transport and engineering infrastructure, the presence of processing enterprises, the proximity of ports and, most importantly, the transparency of economic relations encourage many investors from various industries to create their own or purchase existing agricultural enterprises in order to diversify their business and obtain a stable income in the long term [2-3].

The main factors of stabilization and growth in the agricultural sector are a significant increase in demand, an optimal ratio of prices for products sold, as well as legislative and

\footnotetext{
* Corresponding author: yaninazaiceva@mail.ru
} 
administrative support for the agricultural sector and providing it with material, technical, financial, labor and other resources.

As for inflation indicators, the period of weakening of the ruble exchange rate creates a favorable situation in the market for agricultural producers. Due to the fall in demand for imported goods, the consumption of locally produced products increases, i.e. inflation stimulates both production and demand [4].

\section{Results}

Terms of transactions with land plots in different countries are different. There is a common factor - an increase in its value due to the balance of supply and demand. That is, the open market has turned land into a real asset. And in order to secure this asset, each country has its own system of restrictions on land turnover. It is not always possible for a person to buy a land plot, and often he has to rent it.

The dynamics of changes in the average indicators of agricultural land lease is presented in Table 1. The information is presented up to 2017 inclusive, due to the fact that currently the provision of this information by the Federal Service for State Registration of Cadastre and Cartography "Rosreestr" is not carried out [5-6].

Table 1. Dynamics of changes in average indicators of agricultural land lease transactions

\begin{tabular}{|c|c|c|c|}
\hline Year & Average area, ha & $\begin{array}{c}\text { Average } \\
\text { transaction price, } \\
\text { thousand rubles }\end{array}$ & $\begin{array}{c}\text { Unit price of the } \\
\text { transaction, thousand } \\
\text { rubles/ha }\end{array}$ \\
\hline 2006 & 1.35 & 0.81 & 0.6 \\
\hline 2007 & 10.15 & 9.64 & 0.95 \\
\hline 2008 & 11.94 & 19.82 & 1.66 \\
\hline 2009 & 6.89 & 22.05 & 3.2 \\
\hline 2010 & 2.52 & 1.15 & 0.46 \\
\hline 2011 & 5.14 & 6.16 & 1.2 \\
\hline 2012 & 14.22 & 47.21 & 3.32 \\
\hline 2013 & 17.79 & 173.44 & 9.78 \\
\hline 2014 & 8.11 & 28.54 & 3.52 \\
\hline 2015 & 91.16 & 400.19 & 4.39 \\
\hline 2016 & 14.63 & 134.44 & 9.19 \\
\hline 2017 & 53.01 & 1083.52 & 20.44 \\
\hline
\end{tabular}

The dynamics of price changes is graphically presented in Figures 1, 2. 


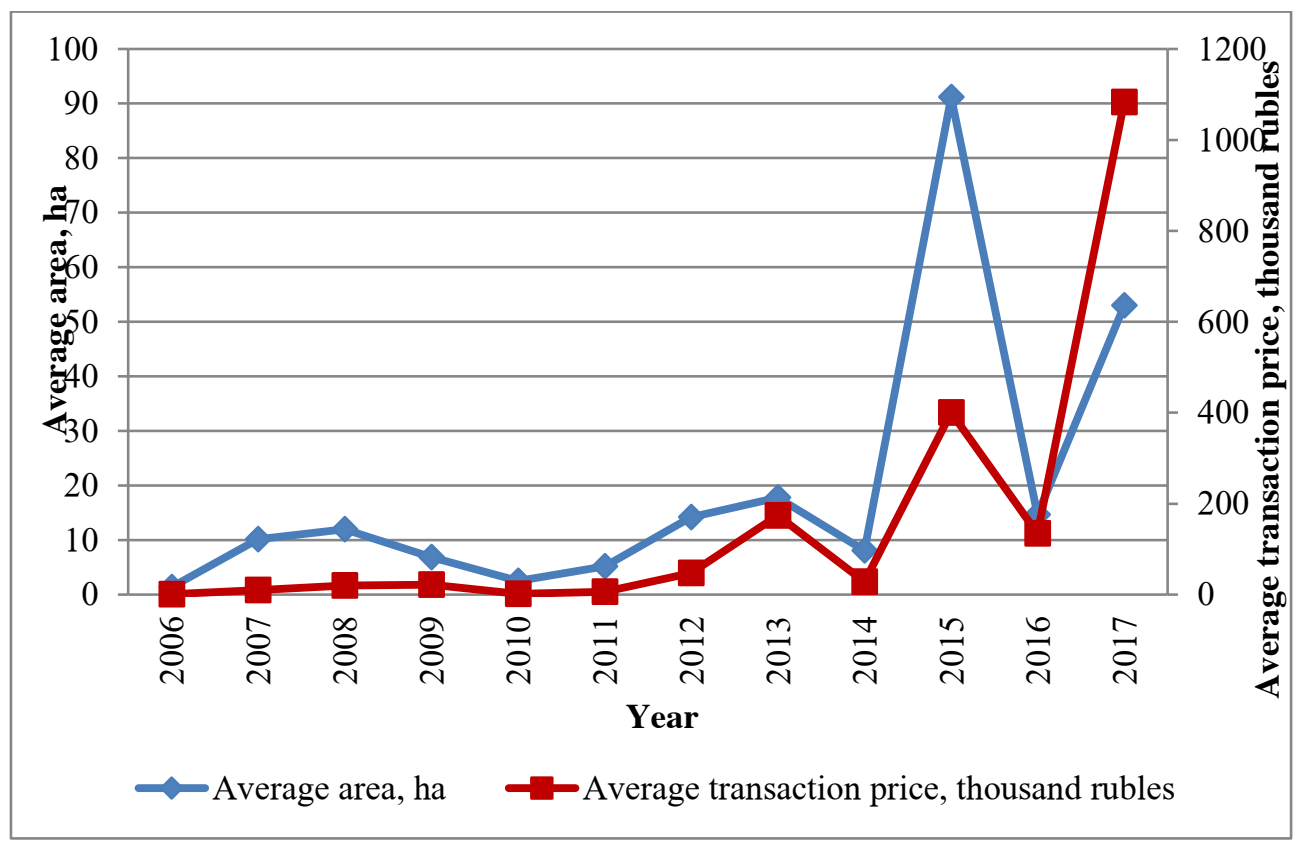

Fig. 1. Dynamics of changes in lease transactions by average area and average transaction price

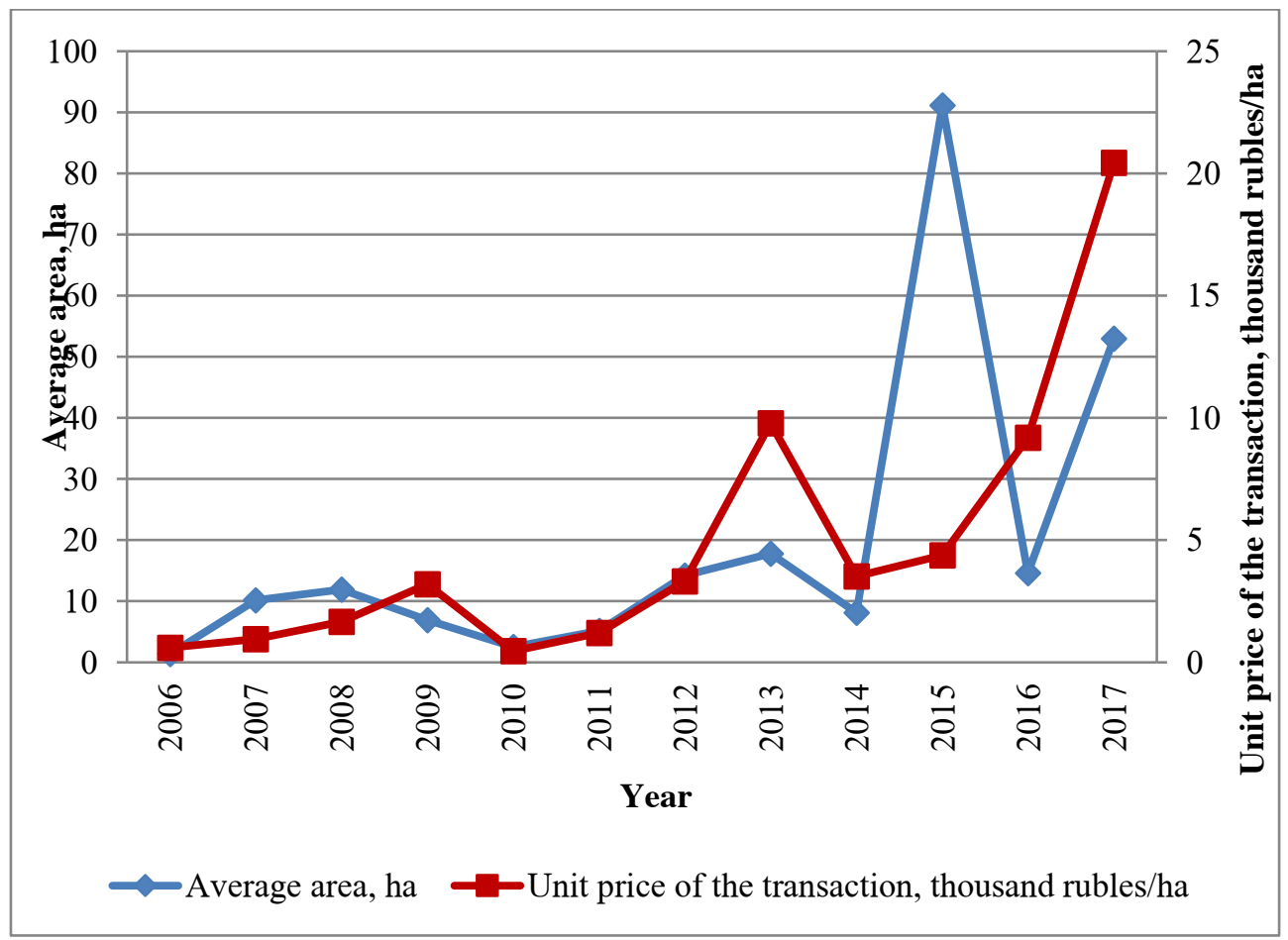

Fig. 2. Dynamics of changes in lease transactions by average area and average unit price of the transaction 


\section{Discussion}

We have analyzed the turnover of agricultural land in the Krasnodar Krai using the example of lease.

We believe that it is necessary to develop a system for monitoring and accounting for the use of agricultural land, which will consist in the annual collection of information on the cultural and technical state of land plots within agricultural land. It is necessary to authorize special bodies that will systematically monitor the state of agricultural land every year. The results of the research should be publicly available, including on a special website on the Internet. Facts of non-use and irrational use of agricultural land plots, deterioration of the ecological situation, reduction of soil fertility should be sent to state land control bodies and local self-government bodies. The results of such studies should be considered factual evidence of the non-use of land plots and taken into account by the courts when making decisions on the seizure of land plots [7-8].

It is also known that the Ministry of Agriculture has developed a state program for the effective commercialization of agricultural land and the development of a reclamation complex. The draft government decree on its approval is posted on the portal of draft regulatory legal acts. The state program will ensure an increase in food security in Russia and the sustainable development of agribusiness, says the explanation to the document.

The first goal of the program is to collect and systematize data on agricultural land. It is planned to collect information on 38.3 million hectares every year. Nowadays, there is no data or it is not reliable and scattered. There is also no single information resource that would answer various questions about the composition, structure of ownership, quality of land, etc., says the explanation to the document. Therefore, it is impossible to analyze the course of land commercialization and effectively manage this process [9].

According to the draft state program, it is planned to approve land management schemes for 44 million hectares of agricultural land in municipalities in ten years: to conduct a survey of lands that are in common ownership, identify unclaimed plots, put plots on cadastral records, etc.

Another goal is to commercialize at least 12 million hectares by 2030. In addition, by this time, the area of reclaimed land should increase by at least 1.6 million hectares compared to the level of 2018, when it was 96.12 thousand hectares. The production of crop products on reclaimed lands in 10 years should increase by $145 \%$ compared to 2018 . At the same time, the degree of depreciation of fixed assets of the land reclamation complex in state ownership should decrease from $78 \%$ in 2020 to $49.9 \%$ in 2030. The Ministry of Agriculture expects that due to the construction and reconstruction of land reclamation facilities, by the end of 2030 , it will be possible to prevent the disposal of up to 3.8 million hectares of reclaimed land from turnover, as well as protect up to 829.3 thousand hectares from water erosion, flooding and waterlogging [10-11].

\section{Conclusion}

The above will fully allow the municipalities to enforce the right of municipalities to register huge areas of ownerless, uncultivated agricultural land in shared ownership under municipal ownership in order to involve them in civil commerce and increase local budget revenues from the use of these lands.

In addition, the new state program envisages increasing soil fertility and maintaining the sustainability of agricultural landscapes on an area of at least 660 thousand hectares through 
agroforestry and phyto-reclamation measures. In 2018, they were carried out on 130.5 thousand hectares. It is also planned to lime 9 million hectares of acidic soils by 2030. This year, according to the state program for the development of agriculture, 1 billion rubles of subsidies should be allocated for soil deacidification. Farmers will be able to receive up to $90 \%$ compensation for the purchase, transportation and reclamation costs.

Thanks to the implementation of the state program, the Ministry of Agriculture plans to provide information support for agricultural producers in the field of land relations and form a market for agricultural land. Concentration of numerous functions in a single institute with innovative approaches and modern IT technologies will make it possible to quickly solve any problems in the development of the country's agribusiness, says the explanation to the document [12-13].

The state program provides for the allocation of subsidies for the preparation of projects for surveying of land plots of common share-holding ownership, cadastral registration of unused lands, as well as for irrigation, land reclamation, agricultural, agroforestry and phytoreclamation activities, and for liming acidic soils.

In our opinion, all of the above measures will certainly give an impetus to the further functioning and development of the agricultural land market, and, accordingly, the country's economy as a whole.

\section{References}

1. Ya. V. Zaitseva, Main directions of further development of the agricultural land market Economy and entrepreneurship, 3(116), 400-402 (2020)

2. Ya. V. Zaitseva, Analysis of the land market in Krasnodar. In the collection: Modern problems and prospects for the development of land and property relations. Collection of articles based on the materials of the All-Russian scientific and practical conference, 334-342 (2019)

3. Ya. V. Zaitseva, Substantiation of the need for land management in the land market. In the book: Scientific support of agribusiness. Collection of abstracts based on the materials of the All-Russian (national conference). Resp. for the issue, 507-508 (Krasnodar, 2019)

4. Ya. V. Zaitseva, Legal regime for the use of agricultural lands. In the collection: Investment management and state investment policy-2. Proceedings of the international scientific conference, 2(91), 753-757 (2018)

5. Ya. V. Zaitseva, Activation of the land market. In the collection: Creativity of young scientists and students in the field of economic sciences. Proceedings of the international complex of scientific publications of youth. Krasnodar, 100-106 (2018)

6. Ya. V. Zaitseva, Prospects of the land market and land relations in the agrarian sector of the economy. Economy and entrepreneurship, 2(91), 753-757 (2018)

7. Ya. V. Zaitseva, State of the agricultural land market in the Krasnodar Krai. Economics and entrepreneurship, 345-347, 12-1(89) (2017)

8. K. I. Mikov, The problem of allocating a land plot from agricultural lands. In the collection: Modern problems and prospects for the development of land and property relations. Collection of articles based on the proceedings of the II All-Russian scientific and practical conference. Resp. for the issue, 452-454 (Krasnodar 2020) 
9. N. M. Radchevsky, State registration and accounting of real estate: a tutorial, 83 (Krasnodar, KubSAU, 2020)

10. N. M. Radchevsky, Substantiation of the need for state regulation of the agricultural land market. Economy and entrepreneurship, 122-125, 12(113) (2019)

11. N. M. Radchevsky, Foreign experience in the development of the land market, Economy and entrepreneurship, 11(112), 1079-1081 (2019)

12. E. Tsoraeva, A. Bekmurzov, S. Kozyrev, A. Khoziev, A. Kozyrev, Environmental issues of agriculture as a consequence of the intensification of the development of agricultural industry E3S Web of Conferences, 215, 02003 (2020) BFT-2020

13. E. Tsoraeva, S. Mezhyan, M. Kataeva, L. Hugaeva, T. Rogova, GIS technologies used in zoning agricultural land for optimizing regional land use E3S Web of Conferences, 224, 03001 (2020) TPACEE-2020 